\title{
Changing RANKL/OPG mRNA expression in differentiating murine primary osteoblasts
}

\author{
G P Thomas, S U K Baker, J A Eisman and E M Gardiner \\ Bone and Mineral Research Program, Garvan Institute of Medical Research, Darlinghurst, New South Wales 2010, Australia \\ (Requests for offprints should be addressed to G P Thomas, Bone and Mineral Research Program, Garvan Institute of Medical Research, 384 Victoria St, \\ Sydney, New South Wales 2010, Australia; Email: g.thomas@garvan.org.au)
}

\begin{abstract}
Osteoblast-osteoclast coordination is critical in the maintenance of skeletal integrity. The modulation of osteoclastogenesis by immature cells of the osteoblastic lineage is mediated through receptor activator of NFKB (RANK), its ligand RANKL, and osteoprotegerin (OPG), a natural decoy receptor for RANKL. Here, the expression of OPG and RANKL in primary mouse osteoblastic cultures was investigated to determine whether the osteoclastogenic stimulus depended on the stage of osteoblastic differentiation and the presence of the calciotrophic hormone 1,25dihydroxyvitamin $\mathrm{D}_{3}\left(1,25-(\mathrm{OH})_{2} \mathrm{D}_{3}\right)$.

OPG mRNA expression was increased in osteoblastic cultures after the onset of mineralisation relative to less mature cultures, but did not alter in response to 1,25$(\mathrm{OH})_{2} \mathrm{D}_{3}$ treatment. In contrast, basal RANKL mRNA expression did not change during differentiation but was significantly enhanced by $1,25-(\mathrm{OH})_{2} \mathrm{D}_{3}$ treatment at all times. The stimulatory effects of $1,25-(\mathrm{OH})_{2} \mathrm{D}_{3}$ on
\end{abstract}

RANKL were lessened in more mature cultures, however. The RANKL/OPG ratio, an index of osteoclastogenic stimulus, was therefore increased by $1,25-(\mathrm{OH})_{2} \mathrm{D}_{3}$ treatment at all stages of osteoblastic differentiation, but to a lesser degree in cultures after the onset of mineralisation. Thus the $1,25-(\mathrm{OH})_{2} \mathrm{D}_{3}$-driven increase in osteoclastogenic potential of immature osteoblasts appears to be mediated by increased RANKL mRNA expression, with mature osteoblasts having relatively decreased osteoclastogenic activity due to increased OPG mRNA expression. These findings suggest a possible mechanism for the recently proposed negative regulatory role of mature osteoblasts on osteoclastogenesis and indicate that the relative proportions of immature and mature osteoblasts in the local microenvironment may control the degree of resorption at each specific bone site.

Journal of Endocrinology (2001) 170, 451-460

\section{Introduction}

Skeletal structure is continually adapting to metabolic and mechanical demands. Osteoblastic (bone forming) and osteoclastic (bone resorbing) cells maintain the integrity of bone during this remodelling process, with tight regulation and coordination of their activities. In vivo histological and in vitro culture studies suggested a role for osteoblastic cells in the direct regulation of osteoclast activity (Rodan \& Martin 1981, Martin \& Ng 1994).

Resorption is stimulated by a number of factors, including the hormones 1,25-dihydroxyvitamin $\mathrm{D}_{3} \quad(1,25-$ $(\mathrm{OH})_{2} \mathrm{D}_{3}$ ) and parathyroid hormone (Teti et al. 1988, Flanagan et al. 1995, Suda et al. 1997). Enhancement of osteoclast differentiation and activity by $1,25-(\mathrm{OH})_{2} \mathrm{D}$ is largely mediated via the immature cells of the osteoblastic lineage (Martin \& Ng 1994). Regulatory factors involved in this interaction have been identified. Stromal and osteoblast precursor cells express a member of the tumour necrosis factor ligand family, receptor activator of NFKB ligand (RANKL), also identified as osteoclast differentia- tion factor (ODF), osteoprotegerin ligand (OPG-L) and tumour necrosis factor-related, activation-induced cytokine (TRANCE) (Anderson et al. 1997, Wong et al. 1997, Lacey et al. 1998, Yasuda et al. 1998b). This cell-surface ligand stimulates osteoclastogenesis and osteoclast activity by binding to its cognate receptor, RANK, also termed ODF receptor (ODFR), on the surface of osteoclast precursors (Hsu et al. 1999). Addition of the cleaved and thus soluble form of RANKL can increase osteoclast formation and activity in vitro (Lacey et al. 1998, Matsuzaki et al. 1998, Yasuda et al. 1998b, Burgess et al. 1999). A further level of regulation is provided by the production of a RANKL 'decoy receptor', osteoprotegerin (OPG) or osteoclastogenesis inhibitory factor (OCIF), by osteoblasts and other cell types (Simonet et al. 1998, Yasuda et al. 1998a). OPG binds to RANKL, blocking its interaction with RANK on osteoclast precursors and thus inhibiting osteoclast activity (Lacey et al. 1998, Yasuda et al. 1998b, Hsu et al. 1999). The importance of this pathway has been demonstrated in OPG knockout mice, which exhibit severe osteoporosis (Bucay et al. 1998, 
Mizuno et al. 1998), and transgenic mice overexpressing OPG, which have osteopetrosis (Simonet et al. 1997). On the basis of these and other studies, it has been suggested that the ratio between $R A N K L$ and $O P G$ expression levels in osteoblastic cells is a key factor in osteoclast regulation (Horwood et al. 1998, Nagai \& Sato 1999).

Previous in vitro studies of OPG/RANK/RANKL regulation have utilised stromal cells, immature primary osteoblasts and osteoblast cell lines (Horwood et al. 1998, Hofbauer et al. 1999, Lee \& Lorenzo 1999, Nagai \& Sato 1999, Shirai et al. 1999, Suda et al. 1999, Yasuda et al. 1999, Deyama et al. 2000). Immature osteoblasts and stromal cells enhance osteoclast recruitment and differentiation (Martin \& Ng 1994). Recent studies using cell lines induced to differentiate into a more mature osteoblastic phenotype have indicated that levels of expression of RANKL and OPG may be altered (Shirai et al. 1999, Deyama et al. 2000). However, the patterns of expression of RANKL and OPG have not been established during primary osteoblastic differentiation.

Primary osteoblasts cultured in vitro progress through a developmental sequence considered to mirror the sequence in vivo, with three overlapping stages of osteoblast differentiation and characteristic patterns of gene expression (Robey \& Tremine 1985, Marie et al. 1989, Owen et al. 1990, Lian et al. 1990). Collagen type 1a1 (COL1; the main structural component of the bone extracellular matrix), is expressed from an early stage during osteoblast differentiation (Owen et al. 1990). Expression of non-collagenous matrix proteins such as osteopontin (OPN) and alkaline phosphatase (ALP), which are believed to stabilise the matrix, is associated with the matrix formation/maturation phase of differentiation (Owen et al. 1990, Stein \& Lian 1993). Osteocalcin, the non-collagenous matrix protein expressed almost exclusively in bone, is up-regulated at the late stage of differentiation coincident with the onset of mineralisation, and thus is believed to have a role in the regulation of this process (Owen et al. 1990, Ducy et al. 1996). The effects of 1,25-dihydroxyvitamin $\mathrm{D}_{3}\left(1,25-(\mathrm{OH})_{2} \mathrm{D}_{3}\right)$ on osteoblasts have been well characterised in rat and human osteoblastic cultures, with both stimulation and inhibition of genes associated with the differentiated osteoblastic phenotype, but an overall inhibitory effect on osteoblast differentiation, particularly by longer-term treatment (Auf mkolk et al. 1985, Owen et al. 1991, Ishida et al. 1993, Siggelkow et al. 1999).

The present study examined primary mouse osteoblasts throughout their developmental sequence and their response to $1,25-(\mathrm{OH})_{2} \mathrm{D}_{3}$ treatment. Basal and 1,25$(\mathrm{OH})_{2} \mathrm{D}_{3}$-stimulated expression patterns of mouse genes encoding bone structural proteins and osteoclastogenic regulators were examined. RANKL mRNA expression was stimulated by $1,25-(\mathrm{OH})_{2} \mathrm{D}_{3}$ at all times, but was down-regulated in untreated late cultures. In contrast, $O P G$ mRNA expression was increased at the onset of mineralisation and remained high throughout, thereby resulting in a lower $R A N K L / O P G$ ratio in mature osteoblasts. These changes in gene expression correlate with the previously proposed lower osteoclastogenic potential of mature osteoblasts in mice and suggest that immature and mature osteoblasts may have different roles in the maintenance of the bone remodelling balance.

\section{Materials and Methods}

\section{Cell culture}

Primary calvarial osteoblast cultures were established from 2-day-old FVB/N mice by enzymatic digestion (Wong \& Cohn 1975), as described previously (Thomas et al. 2000). Briefly, frontal and parietal bones were removed, minced, transferred to digest $\operatorname{mix}(1 \mathrm{mg} / \mathrm{ml}$ collagenase (Boehringer-Mannheim, Mannheim, Germany), 0.05\% trypsin (CSL, Sydney, Australia), 0.02\% EDTA (ICN, Costa Mesa, CA, USA) in PBS; $1 \mathrm{ml} / 5$ calvaria) and stirred for $30 \mathrm{~min}$ at $37^{\circ} \mathrm{C}$. Cells released from the first digest were discarded and the cells released from the second digest were seeded at a density of $10^{4}$ cells per $\mathrm{cm}^{2}$ into six-well plates and cultured in $\alpha$-MEM (Trace, Sydney, Australia) containing 10\% fetal calf serum (Gibco, Grand Island, NY, USA), $100 \mathrm{U} / \mathrm{ml}$ penicillin, $100 \mathrm{mg} /$ $\mathrm{ml}$ streptomycin, $40 \mathrm{mg} / \mathrm{ml}$ gentamycin, $20 \mathrm{mM}$ HEPES, $2 \mathrm{mM}$ glutamine (all Gibco), $10 \mathrm{mM} \beta$-glycerophosphate, $50 \mathrm{mg} / \mathrm{ml}$ ascorbic acid (Sigma, St Louis, MO, USA). Culture medium was changed after 3 days and every 2-3 days thereafter.

Cells were treated with $10^{-8} \mathrm{M} 1,25-(\mathrm{OH})_{2} \mathrm{D}_{3}$ or $0 \cdot 1 \%$ isopropanol vehicle at the time-point indicated and collected for analysis $48 \mathrm{~h}$ later.

\section{Biochemical determinations}

Cells were lysed in $0.5 \mathrm{ml} /$ well of $0.1 \%$ Triton-X100, $0.5 \mathrm{mM} \mathrm{MgCl}_{2}$ in $20 \mathrm{mM}$ Tris base, $\mathrm{pH} 10$ and stored at $-20{ }^{\circ} \mathrm{C}$ until required for assay.

DNA was assayed using a fluorimetric assay (Downs \& Wilfinger 1983, Rao \& Otto 1992). Briefly, 0.05 ml lysate was mixed with $0.2 \mathrm{ml}$ of $1 \mathrm{mg} / \mathrm{ml}$ bisbenzimide in water in clear polystyrene $96-$ well plates in duplicate, allowed to stand for $5 \mathrm{~min}$, then read on a Fluoroskan II (Labsystems, Helsinki, Finland) with excitation at $355 \mathrm{~nm}$ and emission at $460 \mathrm{~nm}$. DNA values were calculated using the DeltaSoft analytical software (Biometallics, Princeton, NJ, USA) and expressed as $\mu \mathrm{g}$ DNA.

ALP concentrations in the cell lysates were assayed by colourimetry (Lowry et al. 1954). Lysate $(0.25 \mathrm{ml})$ was incubated at $37^{\circ} \mathrm{C}$ for $15 \mathrm{~min}$ with $0.075 \mathrm{ml}$ AMP buffer (0.075 M AMP 221 buffer (Sigma), $10 \mathrm{mM} \mathrm{MgCl}_{2}$, $2 \mathrm{mg} / \mathrm{ml}$-nitrophenol phosphate) in clear polystyrene 96-well plates. $\mathrm{NaOH}(0 \cdot 1 \mathrm{ml}$ of $0.5 \mathrm{M})$ was added to stop 
the reaction and the plates were read at $405 \mathrm{~nm}$. ALP concentrations were calculated against a $p$-nitrophenol standard curve. Values are expressed as mol $p$-nitrophenol produced per $\mu \mathrm{g}$ DNA per h.

Osteocalcin concentrations in the culture medium were determined by radioimmunoassay (Gundberg et al. 1992) in $50 \mu \mathrm{l}$ samples and expressed as ng osteocalcin per $\mu \mathrm{g}$ DNA. Primary antibody and osteocalcin standards were kindly provided by C Gundberg (New Haven, CT, USA). Iodinated osteocalcin was purchased from Biomedical Technologies Inc., Stoughton, MA, USA. Donkey anti-goat IgG secondary antibody was purchased from Sigma.

\section{$R N A$ isolation and analysis}

RNA was isolated from osteoblastic cell cultures in sixwell plates using $1 \mathrm{ml} /$ well of Trizol reagent (Gibco) with $5 \mu \mathrm{g}$ glycogen as carrier. RNA $(15 \mu \mathrm{g})$ was analysed by northern blot analysis on a nylon filter (HybondN+, Amersham, Buckinghamshire, UK), and probed with the random primed $\alpha-{ }^{32} \mathrm{P}-\mathrm{dCTP}$ labelled osteocalcin probe followed, after stripping, by the mouse osteopontin, COL1, $O P G, R A N K L$ and GAPDH probes. Radioactivity bound to the filter was measured on a phosphorimager (Molecular Dynamics, Sunnyvale, CA, USA) and normalised to the GAPDH signal.

\section{Semi-quantitative RT-PCR}

Total RNA was isolated as for the northern blot analysis. cDNAs were generated by reverse transcriptase (Superscript II, Gibco) with random hexamer primers. PCR amplification was carried out with gene-specific primers (Sigma) using Taq polymerase (Amplitaq, Perkin Elmer, Norwalk, CT, USA). Reactions were carried out in foil-sealed 96-well plates (Thermofast 96, ABGene, Epsom, Surrey, UK) on a GeneAmp 9700 machine (Perkin Elmer). Both OPG and RANKL were duplexed with $G A P D H$ after conditions were optimised to produce linear amplification for both genes. For both $O P G-G A P D H$ and $R A N K L-G A P D H$, annealing temperatures were $65^{\circ} \mathrm{C}$ with the reactions run for 29 cycles. Specific primers were as follows: OPG (product $578 \mathrm{bp}$ ) forward 5'-TCCTG GCACCTACCTAAAACAGCA-3', reverse 5'-CTAC ACTCTCGGCATTCACTTTGG-3'; RANKL (product $394 \mathrm{bp)}$ forward 5'-CACACCTCACCATCAATGCT GC-3', reverse 5'-GAAGGGTTGGACACCTGAA TGC-3'; GAPDH (product $983 \mathrm{bp}$ ) forward 5'GGTCGGTGTGAACGGATTTGG-3', reverse $5^{\prime}$ ATGTAGGCCATGAGGTCCACC-3'. PCR products were run on $1.5 \%$ agarose gels, stained with ethidium bromide, the image captured using GelDoc (BioRad, Hercules, CA, USA) and the bands quantified using MolecularAnalyst software (BioRad). Data are represented as the ratio to GAPDH PCR product.

\section{Statistical analysis}

Data shown are from at least two separate culture experiments and are the means of four to six replicates in each experiment for biochemical determinations. For RNA analysis, three experiments were conducted with two to six replicates in each experiment. Statistical comparisons were carried out by ANOVA using SuperAnova software (Abacus Concepts, Berkeley, CA, USA).

\section{Results}

\section{Osteoblast phenotype}

$\mathrm{FVB} / \mathrm{N}$ primary mouse osteoblasts progressed through the osteoblastic developmental sequence, reaching confluence after approximately 10 days of culture, followed by matrix formation and maturation. At approximately 10 days post-confluence, mineralisation was detectable and continued for a further 20 days (as determined by visual inspection). These phases were reflected in the patterns of expression of key genes such as COL1, ALP, osteopontin and osteocalcin, and in mineralisation (Fig. 1). Osteopontin mRNA expression was evident at confluence and did not change significantly throughout the culture period. COL1 mRNA expression was high at confluence and decreased markedly by 10 days post-confluence before increasing at 20 and 30 days post-confluence. Although osteocalcin protein was measurable at confluence, its mRNA was negligible by northern blot analysis at this time-point. The increase in osteocalcin mRNA at later times (20 and 30 days post-confluence) was not as marked as the increase in osteocalcin protein. The ALP protein profile was similar to that of osteocalcin protein. Mineralisation, as measured by uptake of calcium-45, was low during the matrix maturation phase ( 8 days post-confluence) but increased through days 17 to 25 days post confluence (Fig. 1).

The effects of short-term $1,25-(\mathrm{OH})_{2} \mathrm{D}_{3}$ treatment on expression of individual genes varied (Fig. 1). Osteocalcin RNA was reduced at all times post-confluence and osteocalcin protein was decreased by 20 days postconfluence. Osteopontin mRNA was strongly up-regulated by $1,25-(\mathrm{OH})_{2} \mathrm{D}_{3}$ throughout the culture period. In contrast, there was no consistent effects of $1,25-(\mathrm{OH})_{2} \mathrm{D}_{3}$ on COL1 mRNA expression. ALP protein was decreased after $1,25-(\mathrm{OH})_{2} \mathrm{D}_{3}$ treatment at both time-points postconfluence. Short-term (2 day) treatment with 1,25$(\mathrm{OH})_{2} \mathrm{D}_{3}$ inhibited mineralisation at 8 and 17 days post-confluence.

\section{Osteoclastogenesis regulatory genes}

RANKL RNA levels, measured by semi-quantitative RT-PCR, were evident at confluence, increased at 10 days post-confluence, then returned to confluence values at 20 days and remained low at 30 days post-confluence 
A

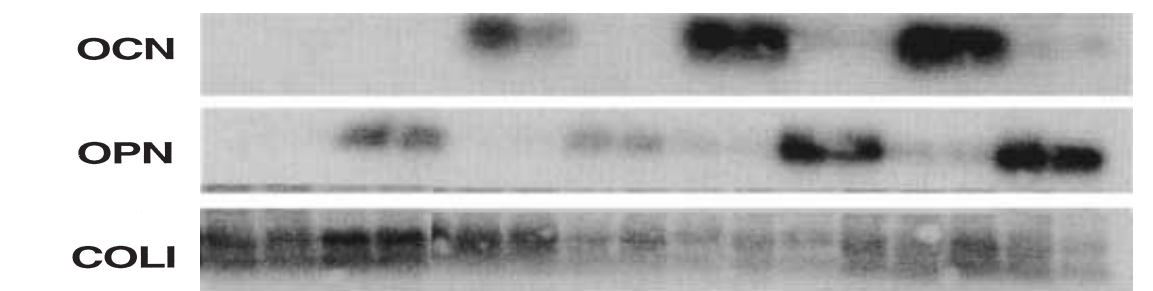

\section{GAPDH}
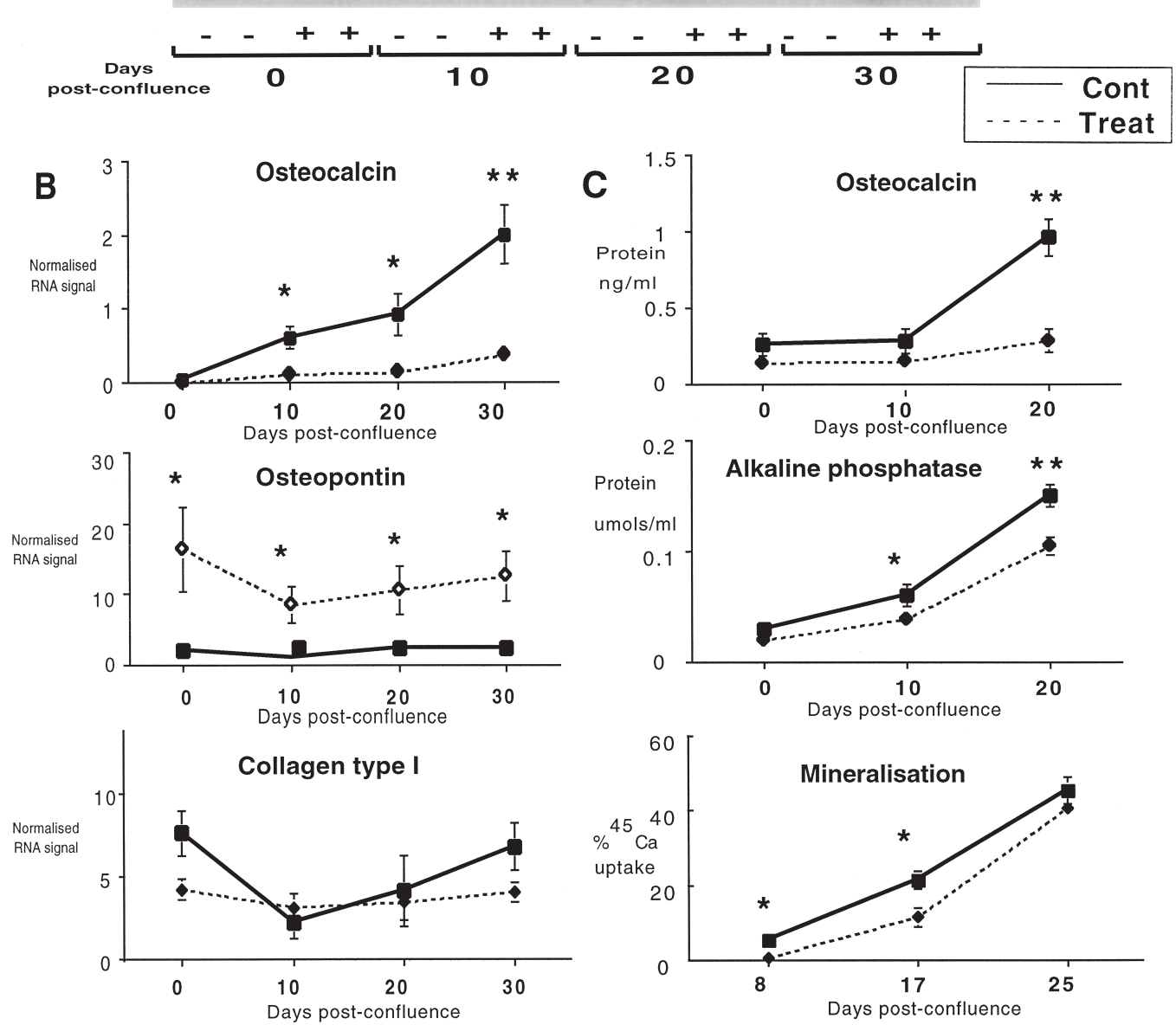

Figure 1 Osteoblast gene expression in primary osteoblast cultures. (A) Northern blot showing expression of genes in basal conditions and in 1,25- $(\mathrm{OH})_{2} \mathrm{D}_{3}$-treated osteoblasts, at various stages during the culture period. Large changes in osteocalcin $(\mathrm{OCN})$ and osteopontin $(\mathrm{OPN})$ in response to $1,25-(\mathrm{OH})_{2} \mathrm{D}_{3}$ treatment are evident. Data are from duplicate wells. On longer exposures (not shown), signal was evident in all lanes of vehicle-treated cultures. (B) Expression of the osteocalcin gene was low at confluence and increased as differentiation progressed and was decreased significantly by $1,25(\mathrm{OH})_{2} \mathrm{D}_{3}$ treatment at all time-points post-confluence. Osteopontin RNA levels were relatively stable throughout the time course and were significantly increased by $1,25(\mathrm{OH})_{2} \mathrm{D}_{3}$ treatment at all time-points. COL1 (Collagen type 1) RNA expression was high at confluence, decreased by 10 days post-confluence then increased again by 30 days post-confluence, but showed no response to $1,25(\mathrm{OH})_{2} \mathrm{D}_{3}$ treatment. (C) Osteocalcin and ALP (Alkaline phosphatase) protein levels both increased markedly after the onset of mineralisation (beyond 10 days post-confluence). Treatment with $1,25(\mathrm{OH})_{2} \mathrm{D}_{3}$ decreased osteocalcin protein at 20 days post-confluence and ALP at 10 and 20 days post confluence. Mineralisation increased with the progression of differentiation in the cultures and was significantly inhibited by $1,25(\mathrm{OH})_{2} \mathrm{D}_{3}$ treatment at 8 and 17 days, but not 25 days post-confluence. Note the different time-points of the experiments. Cont (-), vehicle-treated; Treat $(---), 1,25-(\mathrm{OH})_{2} \mathrm{D}_{3}$-treated. Values are means \pm S.E.M. of two or three experiments with two to four replicates. ${ }^{*} P<0 \cdot 05,{ }^{*} P<0 \cdot 01,1,25-(\mathrm{OH})_{2} \mathrm{D}_{3}$-treated compared with vehicle-treated cultures. 
A

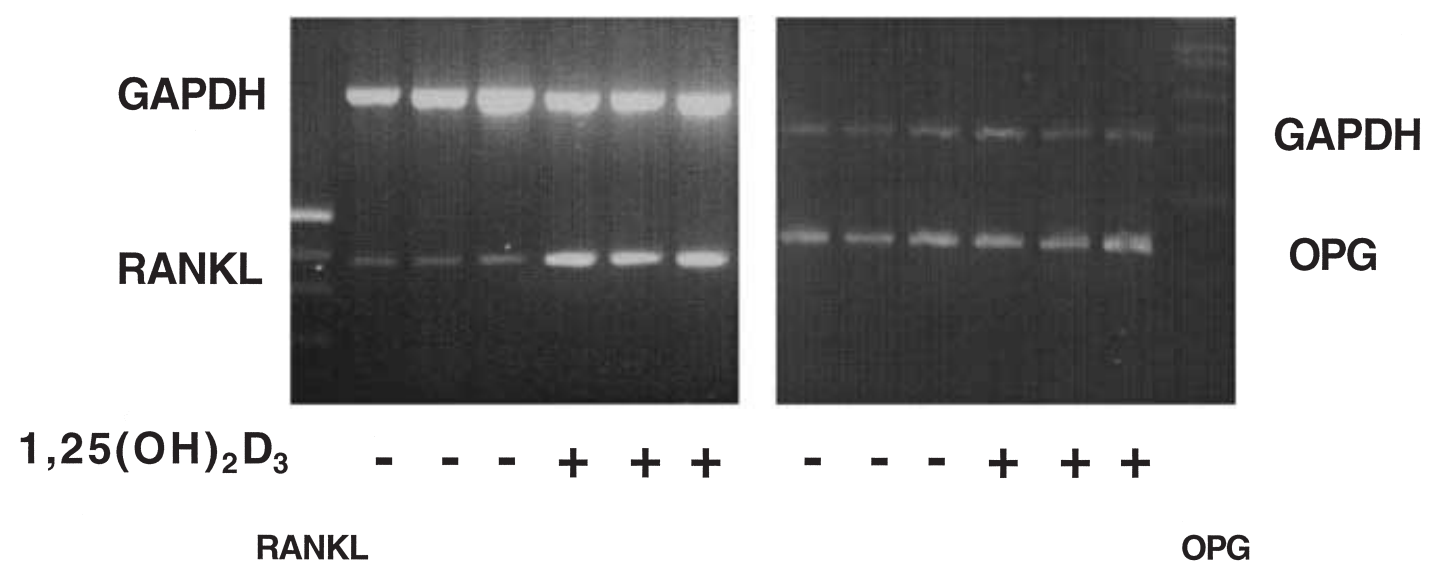

B
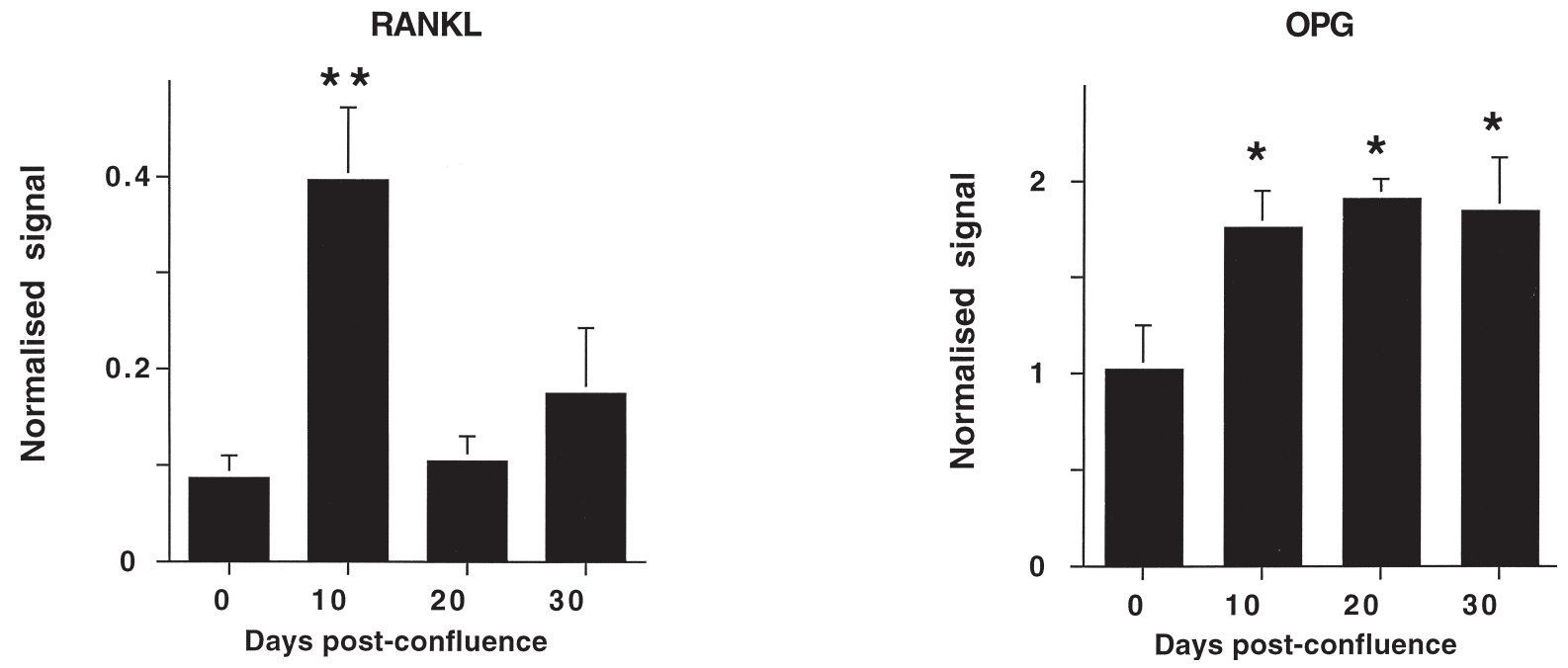

Figure 2 Levels of expression of osteoclastic regulatory molecules (RANKL and OPG) during osteoblast development in primary cultures. (A) Representative semi-quantitative RT-PCR for RANKL and OPG at 10 days post-confluence with and without $1,25-(\mathrm{OH})_{2} \mathrm{D}_{3}$ treatment. The upper band represents GAPDH (983 bp) and the lower band RANKL (394 bp) or OPG (578 bp). (B) RANKL and OPG RNA levels in untreated cultures, detected by semi-quantitative RT-PCR. RANKL expression increased between confluence and 10 days later, then returned to basal values at 20 and 30 days post-confluence. OPG expression increased by 10 days post-confluence relative to levels at confluence and remained increased at 20 and 30 days post-confluence. Values are means \pm S.E.M. of three experiments with two to six replicates. ${ }^{*} P<0 \cdot 05,{ }^{*} P<0 \cdot 01$, time-point compared with confluent cultures.

(Fig. 2). OPG RNA was evident at confluence, increased by 10 days post-confluence and remained at a similar level thereafter (Fig. 2).

The effects of $1,25-(\mathrm{OH})_{2} \mathrm{D}_{3}$ treatment on expression of $R A N K L$ and $O P G$ mRNAs were examined at various times up to 30 days post-confluence (Fig. 3). RANKL mRNA expression was increased by $1,25-(\mathrm{OH})_{2} \mathrm{D}_{3}$ treatment at all time-points. This was in contrast to OPG mRNA expression, which did not change in response to $1,25-(\mathrm{OH})_{2} \mathrm{D}_{3}$ treatment. As a consequence, the RANKL/OPG ratio was increased significantly by $1,25-$ $(\mathrm{OH})_{2} \mathrm{D}_{3}$ treatment at all time-points, but to a lesser extent in the more mature primary osteoblastic cells.

\section{Discussion}

Expression of RANKL and OPG, key osteoclast regulatory genes, has previously been characterised predominantly in immature non-mineralising osteoblasts. In the present study, osteoblastic development through to mature mineralising cells was examined in primary cultures, as were the effects of 1,25- $(\mathrm{OH})_{2} \mathrm{D}_{3}$ treatment on gene expression during this differentiation sequence. The developmental profile of mouse primary osteoblasts has been described previously (Lian et al. 1997, Thomas et al. 2000), although RANKL and OPG gene expression in fully mature mineralising primary osteoblastic cultures have not been studied.

The three osteoblastic developmental phases (Owen et al. 1991) can be clearly delineated, with the initial proliferative phase during which COL1 and osteopontin mRNA expression were evident, followed by the matrix production and maturation phase in which expression of the non-collagenous proteins osteopontin, ALP and osteocalcin were increased. The final mineralisation phase was marked by the increase in ${ }^{45} \mathrm{Ca}$ uptake concomitant with 

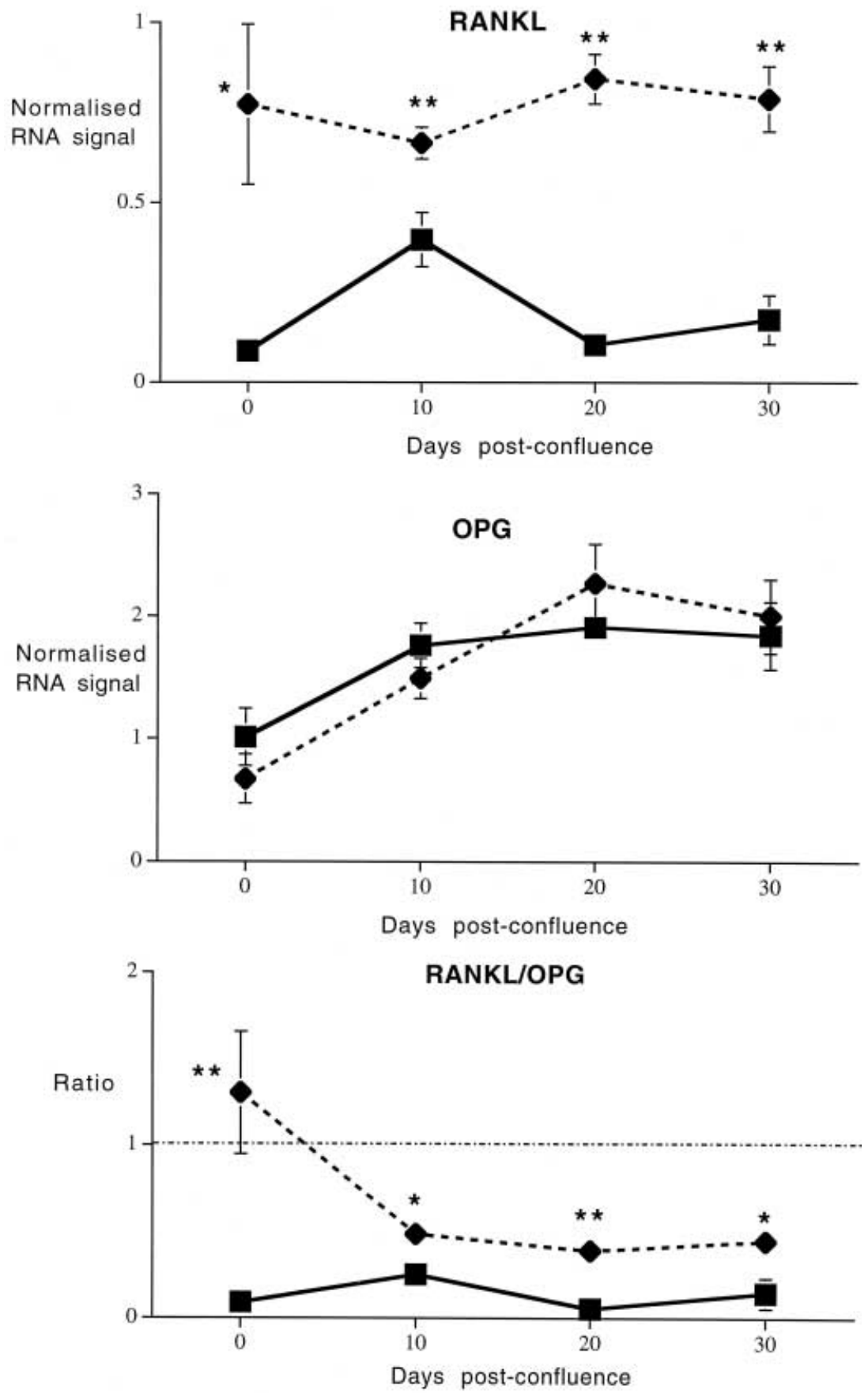

Figure 3 Effects of short-term $1,25(\mathrm{OH})_{2} \mathrm{D}_{3}$ treatment on RANKL and OPG expression levels in osteoblastic cultures, measured by semi-quantitative RT-PCR. RANKL expression was up-regulated at all time-points by $1,25(\mathrm{OH})_{2} \mathrm{D}_{3}$ treatment. OPG expression was unaffected by $1,25(\mathrm{OH})_{2} \mathrm{D}_{3}$ treatment. RANKL/OPG ratios were increased at confluence by

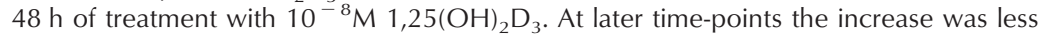
marked. -, Vehicle-treated cultures; - - , 1,25- $(\mathrm{OH})_{2} \mathrm{D}_{3}$-treated cultures. Values are means \pm S.E.M. of three experiments with two to six replicates. ${ }^{*} P<0 \cdot 05,{ }^{* *} P<0 \cdot 01$, $1,25-(\mathrm{OH})_{2} \mathrm{D}_{3}$-treated compared with vehicle-treated cultures. 
further up-regulation of osteocalcin production. This differentiation profile is similar to that of other species (Robey \& Termine 1985, Marie et al. 1989, Owen et al. 1990). The increase in COL1 mRNA expression observed during the later stages of osteoblast differentiation is consistent with a number of other studies in differentiated mouse, but not rat, osteoblasts (Owen et al. 1991, Yamashita et al. 1996, Lian et al. 1997, Qu et al. 1998).

As for other species, $1,25-(\mathrm{OH})_{2} \mathrm{D}_{3}$ treatment suppressed mineralisation of these primary mouse osteoblasts. Changes in gene expression were also consistent with earlier studies, including the inhibition of osteocalcin expression (Clemens et al. 1997, Lian et al. 1997, Sims et al. 1997, Zhang et al. 1997, Thomas et al. 2000) and up-regulation of osteopontin expression (Beresford et al. 1994, Owen et al. 1991, Lian et al. 1997). Short-term $1,25-(\mathrm{OH})_{2} \mathrm{D}_{3}$ treatment had no significant effect on COL1 mRNA expression, consistent with previous studies in mice and other species reporting only minimal differing responses to $1,25-(\mathrm{OH})_{2} \mathrm{D}_{3}$ (Kurihara et al. 1984, Lian et al. 1997, Siggelkow et al. 1999). ALP protein was down-regulated by $1,25-(\mathrm{OH})_{2} \mathrm{D}_{3}$ at all time-points measured, consistent with reports in rat primary osteoblasts (Owen et al. 1991), but contrasting with its up-regulation by $1,25-(\mathrm{OH})_{2} \mathrm{D}_{3}$ in the mouse osteoblastic MC3T3-E1 cell line (Kurihara et al. 1984, Matsumoto et al. 1991). Studies in human primary osteoblasts and cell lines have documented both up-regulation (Murray et al. 1987, Beresford et al. 1994, Harris et al. 1995) and minimal effects (Marie et al. 1989) on ALP by $1,25-(\mathrm{OH})_{2} \mathrm{D}_{3}$. Although mouse bone cells exhibit osteoblastic morphology and general response to $1,25-(\mathrm{OH})_{2} \mathrm{D}_{3}$ treatment that are similar to those in other species, differences in patterns of expression of specific gene and responses to $1,25-(\mathrm{OH})_{2} \mathrm{D}_{3}$ do occur. The significance of these species differences remains to be elucidated.

RANKL, a stimulator of osteoclast differentiation and activity (Yasuda et al. 1998b, Burgess et al. 1999), and $O P G$, the inhibitor of osteoclastogenesis (Simonet et al. 1997, Yasuda et al. 1998a), were differentially expressed during osteoblast development. RANKL mRNA expression was detectable at confluence, increased transiently during matrix formation and initiation of mineralisation, then decreased in cells during the mineralisation phase. OPG mRNA expression was evident from confluence, increased during matrix production and maturation, and remained high in the mineralisation phase. The RANKL/ $O P G$ ratio, an index of osteoclast activation, did not alter significantly over the time-course of the study under basal conditions, with only a slight increase at the onset of mineralisation followed by a return to baseline as mineralisation progressed. Importantly, however, the RANKL/ $O P G$ ratio in response to $1,25-(\mathrm{OH})_{2} \mathrm{D}_{3}$ treatment decreased during maturation of these primary osteoblastic cultures. In this present study, protein levels of RANKL and OPG were not measured. However, recent studies have demonstrated that protein levels of RANKL and OPG closely correlate with mRNA levels in vitro (Hofbauer et al. 1999, Deyama et al. 2000). Furthermore, RANKL and OPG mRNA levels have been shown to correlate with altered resorption in response to physiological stimuli such as calcium concentration (Yasuda et al. 1998b, Takeyama et al. 2000) and hormonal treatment (Lee \& Lorenzo 1999), in pathologic states such as Paget's disease of bone (Menaa et al. 2000) and in a breast cancer bone metastasis model (Thomas et al. 1999).

Unlike the present study of mature mineralising osteoblastic cultures, previous in vitro characterisation of RANKL and OPG expression has focused on immature primary osteoblasts and osteoblastic cell lines. On the basis of these studies, it was previously suggested that regulation of RANKL and OPG by osteotropic agents such as $1,25-(\mathrm{OH})_{2} \mathrm{D}_{3}$ did not occur or was significantly reduced in more mature osteoblastic cell lines (Horwood et al. 1998, Nagai \& Sato 1999). In the present study, however, a significant increase in the $R A N K L / O P G$ ratio was elicited by $1,25-(\mathrm{OH})_{2} \mathrm{D}_{3}$ treatment at all time-points, including the most mature cultures. The up-regulation of RANKL by $1,25-(\mathrm{OH})_{2} \mathrm{D}_{3}$ treatment was consistent with the known osteoclastogenic action of $1,25-(\mathrm{OH})_{2} \mathrm{D}_{3}$ and agrees with a number of recent reports in cell line and immature primary cells (Horwood et al. 1998, Yasuda et al. 1998b, Nagai \& Sato 1999). OPG was not significantly altered by $1,25-(\mathrm{OH})_{2} \mathrm{D}_{3}$, contrasting with its downregulation reported in previous studies in immature osteoblastic cells (Horwood et al. 1998, Murakami et al. 1998). The greater RANKL/OPG ratio in less mature 1,25$(\mathrm{OH})_{2} \mathrm{D}_{3}$-treated confluent cultures, driven by the lower OPG level at this time-point, is consistent with the osteoclastogenic activity of precursor stromal cells and early osteoblasts (Martin \& Ng 1994). The decrease in the RANKL/OPG ratio in more differentiated cultures, whether under basal or 1,25- $(\mathrm{OH})_{2} \mathrm{D}_{3}$-treated conditions, is driven primarily by the relative increase in $O P G$ mRNA expression in mature osteoblasts, as there was little change in RANKL response to $1,25-(\mathrm{OH})_{2} \mathrm{D}_{3}$ during osteoblast development. The fact that OPG is a secreted polypeptide that may act locally or systemically, while RANKL is a cell-surface molecule and therefore can only act locally on neighbouring cells, may also influence this putative regulatory pathway. A recent study reported only partial site-specific rescue of osteopetrosis in RANKLdeficient mice by a lymphocyte-expressed RANKL transgene (Kim et al. 2001).

Recently, a decreased $R A N K L / O P G$ ratio in differentiated MC3T3.E1 osteoblasts was reported (Deyama et al. 2000). In that study, however, reduction of the RANKL/ $O P G$ ratio was driven by decreased expression of $R A N K L$ rather than by the increase in $O P G$ expression seen here, possibly reflecting a difference between established cell lines and primary cultures. The differentiated MC3T3.E1 osteoblasts also exhibited decreased osteoclastogenic 
potential (Deyama et al. 2000), consistent with a previously proposed negative regulatory effect of mature osteoblasts on osteoclast activity (Gardiner et al. 2000). Taken together, these data therefore suggest that altering the RANKL/OPG ratio may provide a simple reciprocal mechanism by which $1,25-(\mathrm{OH})_{2} \mathrm{D}_{3}$ could mediate both stimulation of osteoclastogenesis through immature stromal cells/osteoblasts, and the proposed inhibition of osteoclast activity by mature osteoblasts.

The mechanisms that define the locations at which bone resorption occurs throughout the skeleton have been unexplained. The present data suggest that physical proximity of osteoclastic precursors with both immature and mature osteoblasts may be an important aspect of local regulation of bone resorption during bone turnover.

\section{Acknowledgements}

This work was supported in part by grants from the NIH, USA, the National Health and Medical Research Council of Australia and AZA Research Pty Ltd. Care and treatment of all animals used to prepare primary cultures was in accordance with the Australian Code of Practice for the Care and Use of Animals for Scientific Purposes (1997) and the Animal Research Act (NSW Agriculture) (1985).

\section{References}

Anderson DM, Maraskovsky E, Billingsley WL, Dougall WC, Tometsko ME, Roux ER, Teepe MC, DuBose RF, Cosman D \& Galibert L 1997 A homologue of the TNF receptor and its ligand enhance T-cell growth and dendritic-cell function. Nature $\mathbf{3 9 0}$ 175-179.

Auf'mkolk B, Hauschka PV \& Schwartz ER 1985 Characterization of human bone cells in culture. Calcified Tissue International 37 228-235.

Beresford JN, Joyner CJ, Devlin C \& Triffitt JT 1994 The effects of dexamethasone and 1,25-dihydroxyvitamin D3 on osteogenic differentiation of human marrow stromal cells in vitro. Archives of Oral Biology 39 941-947.

Bucay N, Sarosi I, Dunstan CR, Morony S, Tarpley J, Capparelli C, Scully S, Tan HL, Xu W, Lacey DL, Boyle WJ \& Simonet WS 1998 Osteoprotegerin-deficient mice develop early onset osteoporosis and arterial calcification. Genes and Development 12 1260-1268.

Burgess TL, Qian Y, Kaufman S, Ring BD, Van G, Capparelli C, Kelley M, Hsu H, Boyle WJ, Dunstan CR, Hu S \& Lacey DL 1999 The ligand for osteoprotegerin (OPGL) directly activates mature osteoclasts. Journal of Cell Biology 145 527-538.

Clemens TL, Tang H, Maeda S, Kesterson RA, Demayo F, Pike JW \& Gundberg CM 1997 Analysis of osteocalcin expression in transgenic mice reveals a species difference in vitamin $\mathrm{D}$ regulation of mouse and human osteocalcin genes. Journal of Bone and Mineral Research 12 1570-1576.

Deyama Y, Takeyama S, Koshikawa M, Shirai Y, Yoshimura Y, Nishikata M, Suzuki K \& Matsumoto A 2000 Osteoblast maturation suppressed osteoclastogenesis in coculture with bone marrow cells. Biochemical \& Biophysical Research Communications 274 249-254.
Downs TR \& Wilfinger WW 1983 Fluorimetric quantification of DNA in cells and tissue. Analytical Biochemistry 131 538-547.

Ducy P, Desbois C, Boyce B, Pinero G, Story B, Dunstan C, Smith E, Bonadio J, Goldstein S, Gundberg C, Bradley A \& Karsenty G 1996 Increased bone formation in osteocalcin-deficient mice. Nature $382448-452$.

Flanagan AM, Stow MD, Kendall N \& Brace W 1995 The role of 1,25-dihydroxycholecalciferol and prostaglandin E2 in the regulation of human osteoclastic bone resorption in vitro. International Journal of Experimental Pathology 76 37-42.

Gardiner E, Baldock P, Thomas G, Hollis B, White C, Sunn K, Morrison N, Walsh W \& Eisman J 2000 Increased formation and decreased resorption of bone in mice with elevated vitamin $D$ receptor in mature osteoblasts. FASEB Journal 14 1908-1916.

Gundberg CM, Clough ME \& Carpenter TO 1992 Development and validation of a radioimmunoassay for mouse osteocalcin: paradoxical response in the Hyp mouse. Endocrinology 130 1909-1915.

Harris SA, Enger RJ, Riggs BL \& Spelsberg TC 1995 Development and characterization of a conditionally immortalized human fetal osteoblastic cell line. Journal of Bone and Mineral Research $\mathbf{1 0}$ 178-186.

Hofbauer LC, Gori F, Riggs BL, Lacey DL, Dunstan CR, Spelsberg TC \& Khosla S 1999 Stimulation of osteoprotegerin ligand and inhibition of osteoprotegerin production by glucocorticoids in human osteoblastic lineage cells: potential paracrine mechanisms of glucocorticoid-induced osteoporosis. Endocrinology 140 $4382-4389$

Horwood NJ, Elliott J, Martin TJ \& Gillespie MT 1998 Osteotropic agents regulate the expression of osteoclast differentiation factor and osteoprotegerin in osteoblastic stromal cells. Endocrinology 139 4743-4746.

Hsu H, Lacey DL, Dunstan CR, Solovyev I, Colombero A, Timms E, Tan HL, Elliott G, Kelley MJ, Sarosi I, Wang L, Xia XZ, Elliott R, Chiu L, Black T, Scully S, Capparelli C, Morony S, Shimamoto G, Bass MB \& Boyle WJ 1999 Tumor necrosis factor receptor family member RANK mediates osteoclast differentiation and activation induced by osteoprotegerin ligand. PNAS 96 3540-3545.

Ishida H, Bellows CG, Aubin JE \& Heersche JN 1993 Characterization of the 1,25-(OH)2D3-induced inhibition of bone nodule formation in long-term cultures of fetal rat calvaria cells. Endocrinology 132 61-66.

Kim N, Odgren PR, Kim D, Marks SC Jr \& Choi Y 2001 Diverse roles of the tumour necrosis factor family member TRANCE in skeletal physiology revealed by TRANCE deficiency and partial rescue by a lymphocyte-expressed TRANCE transgene. PNAS $\mathbf{9 7}$ 10905-10910.

Kurihara N, Ikeda K, Hakeda Y, Tsunoi M, Maeda N \& Kumegawa M 1984 Effect of 1,25-dihydroxyvitamin D3 on alkaline phosphatase activity and collagen synthesis in osteoblastic cells, clone MC3T3-E1. Biochemical and Biophysical Research Communications 119 767-771.

Lacey DL, Timms E, Tan HL, Kelley MJ, Dunstan CR, Burgess T, Elliott R, Colombero A, Elliott G, Scully S, Hsu H, Sullivan J, Hawkins N, Davy E, Capparelli C, Eli A, Qian YX, Kaufman S, Sarosi I, Shalhoub V, Senaldi G, Guo J, Delaney J \& Boyle WJ 1998 Osteoprotegerin ligand is a cytokine that regulates osteoclast differentiation and activation. Cell 93 165-716.

Lee SK \& Lorenzo JA 1999 Parathyroid hormone stimulates TRANCE and inhibits osteoprotegerin messenger ribonucleic acid expression in murine bone marrow cultures: correlation with osteoclast-like cell formation. Endocrinology 140 3552-3561.

Lian JB, Shalhoub V, Aslam F, Frenkel B, Green J, Hamrah M, Stein GS \& Stein JL 1997 Species-specific glucocorticoid and 1,25-dihydroxyvitamin D responsiveness in mouse MC3T3-E1 osteoblasts: dexamethasone inhibits osteoblast differentiation and vitamin D down-regulates osteocalcin gene expression. Endocrinology $1382117-2127$. 
Lowry OH, Roberts NR \& Wu ML 1954 The quantitative histochemistry of the brain. II. Enzyme measurements. Journal of Biological Chemistry 207 19-28.

Marie PJ, Lomri A, Sabbagh A \& Basle M 1989 Culture and behavior of osteoblastic cells isolated from normal trabecular bone surfaces. In Vitro Cellular and Developmental Biology 25 373-380.

Martin TJ \& Ng KW 1994 Mechanisms by which cells of the osteoblast lineage control osteoclast formation and activity. Journal of Cellular Biochemistry 56 357-366.

Matsumoto T, Igarashi C, Takeuchi Y, Harada S, Kikuchi T, Yamato H \& Ogata E 1991 Stimulation by 1,25-dihydroxyvitamin D3 of in vitro mineralization induced by osteoblast-like MC3T3-E1 cells. Bone 12 27-32.

Matsuzaki K, Udagawa N, Takahashi N, Yamaguchi K, Yasuda H, Shima N, Morinaga T, Toyama Y, Yabe Y, Higashio K \& Suda T 1998 Osteoclast differentiation factor (ODF) induces osteoclast-like cell formation in human peripheral blood mononuclear cell cultures. Biochemical and Biophysical Research Communications 246 199-204.

Menaa C, Reddy SV, Kurihara N, Maeda H, Anderson D, Cundy T, Cornish J, Singer FR, Bruder JM \& Roodman GD 2000 Enhanced RANK ligand expression and responsivity of bone marrow cells in Paget's disease of bone. Journal of Clinical Investigation 105 1833-1838.

Mizuno A, Amizuka N, Irie K, Murakami A, Fujise N, Kanno T, Sato Y, Nakagawa N, Yasuda H, Mochizuki S, Gomibuchi T, Yano K, Shima N, Washida N, Tsuda E, Morinaga T, Higashio K \& Ozawa H 1998 Severe osteoporosis in mice lacking osteoclastogenesis inhibitory factor/osteoprotegerin. Biochemical and Biophysical Research Communications 247 610-615.

Murakami T, Yamamoto M, Ono K, Nishikawa M, Nagata N, Motoyoshi K \& Akatsu T 1998 Transforming growth factor-beta1 increases mRNA levels of osteoclastogenesis inhibitory factor in osteoblastic/stromal cells and inhibits the survival of murine osteoclast-like cells. Biochemical and Biophysical Research Communications 252 747-752.

Murray E, Provvedini D, Curran D, Catherwood B, Sussman H \& Manolagas S 1987 Characterization of a human osteoblastic osteosarcoma cell line (SAOS-2) with high bone alkaline phosphatase activity. Journal of Bone and Mineral Research 2 231-238.

Nagai M \& Sato N 1999 Reciprocal gene expression of osteoclastogenesis inhibitory factor and osteoclast differentiation factor regulates osteoclast formation. Biochemical and Biophysical Research Communications 257 719-723.

Owen TA, Aronow M, Shalhoub V, Barone LM, Wilming L, Tassinari MS, Kennedy MB, Pockwinse S, Lian JB \& Stein GS 1990 Progressive development of the rat osteoblast phenotype in vitro: reciprocal relationships in expression of genes associated with osteoblast proliferation and differentiation during formation of the bone extracellular matrix. Journal of Cellular Physiology 143 420-430.

Owen TA, Aronow MS, Barone LM, Bettencourt B, Stein GS \& Lian JB 1991 Pleiotropic effects of vitamin D on osteoblast gene expression are related to the proliferative and differentiated state of the bone cell phenotype: dependency upon basal levels of gene expression, duration of exposure, and bone matrix competency in normal rat osteoblast cultures. Endocrinology 128 1496-1504.

Qu Q, Perä lä-Heape M, Kapanen A, Dahllund J, Salo J, Väänä nen HK \& Härkönen P 1998 Estrogen enhances differentiation of osteoblasts in mouse bone marrow culture. Bone 22 201-209.

Rao J \& Otto WR 1992 Fluorimetric DNA assay for cell growth estimation. Analytical Biochemistry 207 186-192.

Robey PG \& Termine JD 1985 Human bone cells in vitro. Calcified Tissue International 37 453-460.

Rodan GA \& Martin TJ 1981 Role of osteoblasts in hormonal control of bone resorption - a hypothesis. Calcified Tissue International 33 349-531.

Shirai Y, Yoshimura Y, Yawaka Y, Hasegawa T, Kikuiri T, Takeyama S, Matsumoto A \& Oguchi H 1999 Effect of extracellular calcium concentrations on osteoclast differentiation in vitro. Biochemical and Biophysical Research Communications 265 484-488.

Siggelkow H, Schulz H, Kaesler S, Benzler K, Atkinson MJ \& Hüfner M 1999 1,25 dihydroxyvitamin-D3 attenuates the confluencedependent differences in the osteoblast characteristic proteins alkaline phosphatase, procollagen I peptide, and osteocalcin. Calcified Tissue International 64 414-421.

Simonet WS, Lacey DL, Dunstan CR, Kelley M, Chang MS, Lüthy R, Nguyen HQ, Wooden S, Bennett L, Boone T, Shimamoto G, DeRose M, Elliott R, Colombero A, Tan HL, Trail G, Sullivan J, Davy E, Bucay N, Renshaw-Gegg L, Hughes TM, Hill D, Pattison W, Campbell P \& Boyle WJ 1997 Osteoprotegerin: a novel secreted protein involved in the regulation of bone density. Cell 89 309-319.

Sims NA, White CP, Sunn KL, Thomas GP, Drummond ML, Morrison NA, Eisman JA \& Gardiner EM 1997 Human and murine osteocalcin gene expression: conserved tissue restricted expression and divergent responses to 1,25-dihydroxyvitamin D3 in vivo. Molecular Endocrinology 11 1695-1708.

Stein GS \& Lian JB 1993 Molecular mechanisms mediating proliferation/differentiation interrelationships during progressive development of the osteoblast phenotyp. Endocrine Reviews $\mathbf{1 4}$ 424-442.

Suda T, Jimi E, Nakamura I \& Takahashi N 1997 Role of 1 alpha, 25-dihydroxyvitamin D3 in osteoclast differentiation and function. Methods in Enzymology 282 223-235.

Suda T, Takahashi N, Udagawa N, Jimi E, Gillespie MT \& Martin TJ 1999 Modulation of osteoclast differentiation and function by the new members of the tumor necrosis factor receptor and ligand families. Endocrine Reviews 20 345-357.

Takeyama S, Yoshimura Y, Shirai Y, Deyama Y, Hasegawa T, Yawaka Y, Kikuiri T, Matsumoto A \& Fukuda H 2000 Low calcium environment effects osteoprotegerin ligand/osteoclast differentiation factor. Biochemical and Biophysical Research Communications 276 524-529.

Teti A, Volleth G, Carano A \& Zambonin Zallone A 1988 The effects of parathyroid hormone or 1,25-dihydroxyvitamin D3 on monocyte-osteoclast fusion. Calcified Tissue International 42 302-308.

Thomas RJ, Guise TA, Yin JJ, Elliott J, Horwood NJ, Martin TJ \& Gillespie MT 1999 Breast cancer cells interact with osteoblasts to support osteoclast formation. Endocrinology 140 4451-4458.

Thomas GP, Bourne A, Eisman JA \& Gardiner EM 2000 Species-divergent regulation of human and mouse osteocalcin genes by calciotropic hormones. Experimental Cell Research 258 395-402.

Wong GL \& Cohn DV 1975 Target cells in bone for parathormone and calcitonin are different: enrichment for each cell type by sequential digestion of mouse calvaria and selective adhesion to polymeric surfaces. PNAS 72 3167-3171.

Wong BR, Rho J, Arron J, Robinson E, Orlinick J, Chao M, Kalachikov S, Cayani E, Bartlett FS 3rd, Frankel WN, Lee SY \& Choi Y 1997 TRANCE is a novel ligand of the tumor necrosis factor receptor family that activates c-Jun $\mathrm{N}$-terminal kinase in $\mathrm{T}$ cells. Journal of Biological Chemistry 272 25190-25194.

Yamashita T, Ishii H, Shimoda K, Sampath TK, Katagiri T, Wada M, Osawa T \& Suda T 1996 Subcloning of three osteoblastic cell lines with distinct differentiation phenotypes from the mouse osteoblastic cell line KS-4. Bone 19 429-436.

Yasuda H, Shima N, Nakagawa N, Mochizuki SI, Yano K, Fujise N, Sato Y, Goto M, Yamaguchi K, Kuriyama M, Kanno T, Murakami A, Tsuda E, Morinaga T \& Higashio K 1998a Identity of osteoclastogenesis inhibitory factor (OCIF) and osteoprotegerin (OPG): a mechanism by which OPG/OCIF inhibits osteoclastogenesis in vitro. Endocrinology 139 1329-1337.

Yasuda H, Shima N, Nakagawa N, Yamaguchi K, Kinosaki M, Mochizuki S, Tomoyasu A, Yano K, Goto M, Murakami A, Tsuda E, Morinaga T, Higashio K, Udagawa N, Takahashi N \& Suda T 
$1998 b$ Osteoclast differentiation factor is a ligand for osteoprotegerin/ osteoclastogenesis-inhibitory factor and is identical to TRANCE/ RANKL. PNAS 95 3597-3602.

Yasuda H, Shima N, Nakagawa N, Yamaguchi K, Kinosaki M, Goto M, Mochizuki SI, Tsuda E, Morinaga T, Udagawa N, Takahashi N, Suda T \& Higashio K 1999 A novel molecular mechanism modulating osteoclast differentiation and function. Bone 25 109-113.
Zhang R, Ducy P \& Karsenty G 1997 1,25-dihydroxyvitamin D3 inhibits osteocalcin expression in mouse through an indirect mechanism. Journal of Biological Chemistry 272 110-116.

Received 18 January 2001

Accepted 26 April 2001 